УДК 657

DOI: $10.15673 /$ fie.v12i2.1744

\author{
Яценко В.Ф. \\ кандидат економічних наук, доцент \\ кафедра обліку і оподаткування \\ Херсонський державний аграрний університет \\ вул. Стрітенська, 23, м. Херсон, Україна, 73006 \\ E-mail viktorijajacenko@gmail.com \\ ORCID ID: 0000-0001-7127-1885
}

\title{
ЩО ТАКЕ «ТРАДИЦІЙНА» ТЕОРІЯ БУХГАЛТЕРСЬКОГО ОБЛІКУ ТА ЧОМУ Ï̈ КРИТИКУЮТЬ?
}

В статті проведений огляд вітчизняної і зарубіжної академічної літератури, проаналізовані критичні зауваження щодо існуючої теорії бухгалтерського обліку вітчизняними науковцями та співставленні з позицією зарубіжних колег. Контент-аналіз терміну «традиційна» у сфері бухгалтерського обліку дозволив узагальнити підходи до його використання. Зафіксовано значний вплив західних тенденцій на розвиток поглядів вітчизняних науковців на теорію бухгалтерського обліку. Проведене дослідження продемонструвало необхідність врахування особливостей історичного шляху становлення вітчизняної економічної системи, яка має суттєвий вплив на розвиток теорії бухгалтерського обліку. Вектор майбутнього розвитку теорії бухгалтерського обліку як результат подолання критичної маси зауважень доводить, що в єдиній обліковій системі окреслюється чітке розмежування двох взаємопов'язаних підсистем: стандартизованого фінансового обліку та управлінського обліку як обліково-аналітичного забезпечення управління підприємством.

Ключові слова: теорія бухгалтерського обліку, фінансовий облік, управлінський облік, традиційна теорія бухгалтерського обліку, традиційний облік.

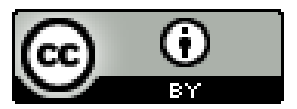

This work is licensed under a Creative Commons Attribution 4.0 International License http://creativecommons.org/licenses/by/4.0/
Постановка проблеми та її зв'язок з важливими науковими та практичними завданнями. Розвиток бухгалтерського обліку як еволюційний процес походить з реальних проблем, до розв'язання яких залучають вчених і практиків. 3 прагматичної точки зору доречно розглянути результат спільного пошуку способів подолання наявних проблем фахівцями реального сектору економіки та науковцями, що у підсумку сприяло покращенню науки про бухгалтерський облік і досягненню позитивних практичних результатів в управлінні українськими підприємствами.

Аналіз останніх публікацій по проблемі. За майже три десятиліття після набуття Україною незалежності збільшувалася множина критичних публікацій і академічних текстів, в яких підкреслювалася невідповідність традиційної теорії бухгалтерського обліку новим умовам функціонування підприємств, та було здійснено перші спроби щодо іiі подолання. Напрацювання плеяди видатних вітчизняних вчених [1-13] увійшли до царини науки про бухгалтерський облік. Однак більшу частину наукових досліджень 3 бухгалтерського обліку було зосереджено на коментуванні недоліків існуючої теорії та невдач у експериментах 3 минулого щодо ііі покращення, аніж глибокого аналізування наявних проблем і їх вплив на формування вектору майбутнього розвитку бухгалтерського обліку. 3 огляду на те, що бухгалтерський облік надає ключову інформацію для прийняття рішень представникам різних груп стейкхолдерів та на тлі великої кількості критичних публікацій вітчизняних авторів щодо необхідності перегляду традиційної теорії бухгалтерського обліку, потрібно зіставити виявлені невідповідності в обліку, викликані трансформаційними процесами економічної системи та, які до сьогодні певним чином не вдалося усунути, 3 контентом «традиційна», а також дослідити аналогічну критику зарубіжних колег щодо стану бухгалтерського обліку та його теорії.

Формулювання цілей дослідження. Метою статті є (1) огляд академічної вітчизняної і зарубіжної літератури в сфері бухгалтерського обліку, (2) контент-аналіз терміну «традиційна» стосовно теорії бухгалтерського обліку та обговорення вектору іiї майбутнього розвитку як результату подолання критичної маси зауважень.

Відповідно до поставленої мети статтю побудовано наступним чином, в першій частині аналізуються критичні зауваження вітчизняних науковців щодо існуючої теорії бухгалтерського обліку та порівнюються з позицією зарубіжних авторів; другу частину присвячено узагальненню підходів до використання терміну «традиційна» стосовно обліку та його теорії, а також розкривається його контент та роль критики у визначенні вектору еволюційного розвитку обліку. 
Виклад основних результатів та їх обгрунтування. 1. Критика бухгалтерського обліку та його теорії вітчизняними та зарубіжними науковцями на сучасному етапі розвитку економічної системи.
В академічній літературі 3 бухгалтерського обліку представлені різні погляди на стан існуючої теорії бухгалтерського обліку та викладені альтернативні напрями іїі майбутнього розвитку (табл. 1).

Таблиця 1

Критика сучасної теорії бухгалтерського обліку вітчизняними науковцями

\begin{tabular}{|c|c|c|}
\hline $\begin{array}{l}\text { Автор, рік } \\
\text { публікації }\end{array}$ & Цитата & $\begin{array}{c}\text { Термін, що викори- } \\
\text { стовусться }\end{array}$ \\
\hline \multirow{3}{*}{$\begin{array}{c}\text { Пушкар M.C. } \\
(1999,2007)\end{array}$} & $\begin{array}{l}\text { традиційна бухгалтерія грунтувалася на використанні лише методо- } \\
\text { логічного підходу до вивчення об'єктів дослідження, а тому виявила- } \\
\text { ся непідготовленою до тих змін, які відбулися в суспільстві [1, с. 25] }\end{array}$ & $\begin{array}{l}\text { традиційна } \\
\text { бухгалтерія }\end{array}$ \\
\hline & $\begin{array}{l}\text { існуюча теорія так званого «бухгалтерського обліку» вичерпала свій } \\
\text { інтелектуальний ресурс [2, с. 2] }\end{array}$ & $\begin{array}{l}\text { теорія бухгалтерсь- } \\
\text { кого обліку }\end{array}$ \\
\hline & $\begin{array}{l}\text { теорія обліку не розвинута і в ній знайшло відображення в описовій } \\
\text { формі того варіанту обробки даних, який відомий нам з часів серед- } \\
\text { ньовіччя (Л. Пачолі, } 1494 \text { р.). В теорії описано лише процедури обро- } \\
\text { бки даних, а не теоретичні положення [3, с. 45]. }\end{array}$ & теорія обліку \\
\hline $\begin{array}{l}\text { Соколов Я.В. } \\
\text { (2003) }\end{array}$ & $\begin{array}{l}\text { найближче завдання бухгалтерів полягає в інтеграції поглядів і на- } \\
\text { прямів, у створенні загальної (чистої) теорії бухгалтерського обліку - } \\
\text { науки, якій належить майбутнє [4 ] }\end{array}$ & $\begin{array}{l}\text { загальна (чиста) } \\
\text { теорія }\end{array}$ \\
\hline \begin{tabular}{c|} 
Кіндраць- \\
ка Л. М. (2008)
\end{tabular} & $\begin{array}{l}\text { проблеми теорії бухгалтерського обліку не розв'язуються, а навпаки - } \\
\text { ще більше загострюються [5, с. } 30] . .\end{array}$ & $\begin{array}{l}\text { теорія бухгалтерсь- } \\
\text { кого обліку }\end{array}$ \\
\hline $\begin{array}{l}\text { Варичева Р.В. } \\
\quad(2010) .\end{array}$ & 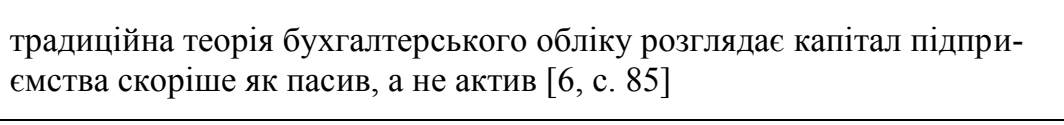 & $\begin{array}{l}\text { традиційна теорія } \\
\text { бухгалтерського } \\
\text { обліку }\end{array}$ \\
\hline $\begin{array}{l}\text { Яремко І.Й. } \\
\quad(2010)\end{array}$ & $\begin{array}{l}\text { Концептуальна основа сучасної теорії бухгалтерського обліку лише } \\
\text { незначною мірою відповідає вимогам інформаційного суспільства та } \\
\text { змісту інформаційно-інтелектуального економічного середовища [7, } \\
\text { с. } 251]\end{array}$ & $\begin{array}{l}\text { теорія } \\
\text { бухгалтерського } \\
\text { обліку }\end{array}$ \\
\hline $\begin{array}{c}\text { Бутинець Ф.Ф, } \\
\text { Бутинець Т.А. } \\
(2012)\end{array}$ & $\begin{array}{l}\text { Єдина загальна теорія обліку є лише бажаною, але бухгалтерський } \\
\text { облік як наука ще знаходиться на досить примітивному рівні розвит- } \\
\text { ку }[8, \text { c.20] }\end{array}$ & $\begin{array}{l}\text { єдина загальна } \\
\text { теорія обліку }\end{array}$ \\
\hline $\begin{array}{l}\text { Жук В.M. } \\
\text { (2012) }\end{array}$ & $\begin{array}{l}\text { Осмілимося пояснити цей «консерватизм» баченням проблеми лише } \\
\text { в рамках радянської «загальної теорії» бухгалтерського обліку.[9, с. } \\
15]\end{array}$ & загальна теорія \\
\hline $\begin{array}{l}\text { Рета М.B. } \\
\text { (2014) }\end{array}$ & $\begin{array}{l}\text { традиційний бухгалтерський облік на сучасному етапі розвитку не } \\
\text { можна вважати стовідсотково придатним для відображення впливів } \\
\text { різноманітних зовнішніх факторів на функціонування підприємства } \\
\text { та ефективність виконання управлінських і контрольних функцій [10, } \\
\text { с. 288]. }\end{array}$ & $\begin{array}{l}\text { традиційний } \\
\text { бухгалтерський } \\
\text { облік }\end{array}$ \\
\hline $\begin{array}{c}\text { Редченко К.І. } \\
\text { (2014) }\end{array}$ & $\begin{array}{l}\text {...традиційний бухгалтерський облік не здатний повністю задоволь- } \\
\text { нити інформаційні потреби різних груп користувачів, оскільки цін- } \\
\text { ність його інформації, яка подається безпосередньо особам, які прий- } \\
\text { мають рішення, є «неповною» }[11, \text { с. } 344] \text {. }\end{array}$ & $\begin{array}{l}\text { традиційний } \\
\text { бухгалтерський } \\
\text { облік }\end{array}$ \\
\hline $\begin{array}{l}\text { Пушкар М.C., } \\
\text { Семанюк B.3. } \\
\text { (2018) }\end{array}$ & $\begin{array}{l}\text { В традиційній обліковій теорії ми не знаходимо категоріальної мат- } \\
\text { риці, яка дозволяє вивчати принципово нові об'єкти, адже ця теорія } \\
\text { сформована для умов індустріального суспільства, а, отже, стає недо- } \\
\text { статньою для наукового пізнання в постіндустріальному суспільстві } \\
{[12, \text { с. } 96] \text {. }}\end{array}$ & $\begin{array}{c}\text { традиційна } \\
\text { облікова теорія }\end{array}$ \\
\hline $\begin{array}{c}\text { Семанюк В.3. } \\
\text { (2018) }\end{array}$ & $\begin{array}{l}\text { Традиційний облік не є ефективним інструментом оцінки, планування } \\
\text { та прийняття рішень, а лише засобом обробки і узагальнення еконо- } \\
\text { мічної інформації, що міститься в первинних документах, а також } \\
\text { інститутом, який співпрацює з фіскальними органами держави задо- } \\
\text { вольняючи їх інформаційні потреби [13, с. 46]. }\end{array}$ & традиційний облік \\
\hline
\end{tabular}

Один 3 найбільш цитованих вітчизняними вченими підручник Е. С. Хендриксен і М.Ф. Ван Бреда проголошує, що єдина загальна теорія обліку $є$ тільки бажаною, це скоріш набір теорій, підтеорій, моделей, які можуть доповнювати одна одну, поєднуватися і конкурувати між собою [14, с. 24]. 
Пошук необхідних англомовних статей проводився за ключовими словами accounting theory (теорія бухгалтерського обліку) в поєднанні з прикметниками traditional або conventional, що українською перекладаються як «традиційна», а також за словосполученнями-синонімами traditional accounting та conventional accounting (традиційний облік) в науковометричній базі Google Scholar. Із масиву публікацій виокремлювалися лише статі, які опубліковані не раніш 2000 року та містять конкретні критичні зауваження щодо сучасного стану бухгалтерського обліку та його теорії.

Результати аналізування академічних текстів зарубіжних вчених у сфері бухгалтерського обліку демонструють аналогічне спрямування критики бухгалтерського обліку та його теорії (табл. 2).

Таблиця 2

Критика бухгалтерського обліку зарубіжними вченими

\begin{tabular}{|c|c|c|}
\hline $\begin{array}{l}\text { Автор (и), рік } \\
\text { публікації }\end{array}$ & Позиція автора (авторів) & $\begin{array}{l}\text { Термін, що вико- } \\
\text { ристовусться }\end{array}$ \\
\hline $\begin{array}{l}\text { Maskell B.H., } \\
\text { Baggaley B.L. } \\
\quad(2006)\end{array}$ & $\begin{array}{l}\text { Традиційні системи обліку характеризують як великі, складні, мар- } \\
\text { нотратні процеси, що вимагають величезної кількості непотрібної } \\
\text { роботи. а також підкреслюють, що мало людей у компанії розумі- } \\
\text { ють звіти, що надходять } 3 \text { системи бухгалтерського обліку, але їх } \\
\text { використовують для прийняття важливих і далекосяжних рішень. } \\
{[15, \text { с. } 35]}\end{array}$ & $\begin{array}{l}\text { traditional accounting } \\
\text { systems }\end{array}$ \\
\hline $\begin{array}{l}\text { Kennedy F.A., } \\
\text { Brewer P.C. } \\
(2006)\end{array}$ & $\begin{array}{l}\text { Традиційний бухгалтерський облік ігнорує нематеріальні нефінан- } \\
\text { сові вимірювання ефективності, такі як своєчасна доставка та задо- } \\
\text { воленість клієнтів. }[16, \text { с.71] }\end{array}$ & traditional accounting \\
\hline $\begin{array}{l}\text { Cooper R., } \\
\text { Maskell B. } \\
\quad(2008)\end{array}$ & $\begin{array}{l}\text { зазначають, що традиційні системи бухгалтерського обліку не при- } \\
\text { значені для виявлення причин несприятливих впливів або виявлен- } \\
\text { ня майбутніх вигод від поліпшення операційних процесів [17, с. } 38] \text {. }\end{array}$ & $\begin{array}{l}\text { traditional accounting } \\
\text { systems }\end{array}$ \\
\hline $\begin{array}{l}\text { Bullen, M.L., } \\
\text { Eyler K. } \\
\text { (2010) }\end{array}$ & $\begin{array}{l}\text { Облік має розглядати витрати на людські ресурси як активи, на від- } \\
\text { міну від традиційного обліку, в якому ці витрати розглядаються як } \\
\text { такі, що зменшують прибуток }[18, \text { с. } 70-85] .\end{array}$ & traditional accounting \\
\hline $\begin{array}{l}\text { Maskell B., } \\
\text { Baggaley B., } \\
\text { Grasso L. } \\
\text { (2012) }\end{array}$ & $\begin{array}{l}\text { До недоліків традиційного обліку відносять: традиційний бухгал- } \\
\text { терський облік надає більше значення змінам витрат (фактичних) } \\
\text { порівняно з плановими, але дані надають занадто пізно, тому не } \\
\text { можуть використовуватися для прийняття управлінських рішень; } \\
\text { традиційний облік стимулює перевиробництво, оскільки збільшена } \\
\text { кількість випущеної продукції знижує сукупні витрати; традиційний } \\
\text { бухгалтерський облік надає складні звіти для тих, хто не обізнаний } \\
\text { в обліку, і це може призвести до неправильних рішень [19, с. 26] }\end{array}$ & traditional accounting \\
\hline $\begin{array}{l}\text { Rosa A.C., } \\
\text { Machado M.J., } \\
(2013)\end{array}$ & $\begin{array}{l}\text { Традиційні фінансові та бухгалтерські системи розглядаються як } \\
\text { неадекватні (системи, спрямовані на масове виробництво та досяг- } \\
\text { нення ефекту масштабу) [20, с. } 889]\end{array}$ & $\begin{array}{l}\text { traditional financial } \\
\text { and accounting } \\
\text { systems }\end{array}$ \\
\hline $\begin{array}{l}\text { McVay G., } \\
\text { Kennedy F., } \\
\text { Fullerton R. } \\
\quad(2013) \\
\end{array}$ & $\begin{array}{l}\text { Традиційна система бухгалтерського обліку надає звіти, доступні } \\
\text { для розуміння лише невеликою кількістю співробітників компанії } \\
{[21] .}\end{array}$ & $\begin{array}{l}\text { traditional accounting } \\
\text { system }\end{array}$ \\
\hline $\begin{array}{l}\text { Ofileanu D., } \\
\text { Topor D.I. } \\
\text { (2014) }\end{array}$ & $\begin{array}{l}\text { Традиційний бухгалтерський облік був створений для масового ви- } \\
\text { робництва, тому сприяє перевиробництву, також він покриває ви- } \\
\text { трати за рахунок максимальної безперервної роботи всього облад- } \\
\text { нання, без врахування запитів клієнтів [22, с. } 345] \text {. }\end{array}$ & traditional accounting \\
\hline $\begin{array}{l}\text { Burritt R., } \\
\text { Christ K. } \\
(2016)\end{array}$ & $\begin{array}{l}\text { Критикують обмеженість традиційного (загальноприйнятого) фі- } \\
\text { нансового обліку та фінансової звітності щодо витрат на захист до- } \\
\text { вкілля [23]. }\end{array}$ & $\begin{array}{l}\text { conventional } \\
\text { financial accounting, } \\
\text { conventional } \\
\text { financial accounting } \\
\text { record }\end{array}$ \\
\hline $\begin{array}{l}\text { Schaltegger S., } \\
\text { Etxeberria I.Á., } \\
\text { Ortas E. } \\
(2017)\end{array}$ & $\begin{array}{l}\text { Існуючі традиційні (загальноприйняті) системи бухгалтерського } \\
\text { обліку перевантажені створенням «істинної» картини [24, с. 114]. }\end{array}$ & $\begin{array}{l}\text { conventional } \\
\text { accounting systems }\end{array}$ \\
\hline $\begin{array}{c}\text { Chabrak N., } \\
\text { Haslam J., } \\
\text { Oakes H. } \\
(2019)\end{array}$ & $\begin{array}{l}\text { Високо оцінюючи критику щодо традиційного (загальноприйнято- } \\
\text { го) обліку та формування альтернативних обліків, ми також прагне- } \\
\text { мо звернутись до сутності різноманітних записів бухгалтерського } \\
\text { обліку, що дотепер використовуються в теорії та практиці [25, с. } \\
\text { 13]. }\end{array}$ & $\begin{array}{l}\text { conventional } \\
\text { accounting }\end{array}$ \\
\hline
\end{tabular}


Продовження табл.2

\begin{tabular}{|c|l|c|}
\hline $\begin{array}{c}\text { Автор (и), рік } \\
\text { публікації }\end{array}$ & Позиція автора (авторів) & $\begin{array}{c}\text { Термін, що викори- } \\
\text { стовується }\end{array}$ \\
\hline $\begin{array}{c}\text { Myrelid А., } \\
\text { Olhager J. } \\
(2019)\end{array}$ & $\begin{array}{l}\text { Те, що зазвичай називають традиційним бухгалтерським обліком, } \\
\text { було розроблено в початку двадцятого сторіччя. Цей підхід був ада- } \\
\text { птований для масового виробництва та складного сучасного вироб- } \\
\text { ництва [26, с. 138] }\end{array}$ & traditional accounting \\
\hline
\end{tabular}

*Сформовано автором

Отже, критика сучасного стану бухгалтерського обліку та його теорії об'єднала більшість вітчизняних і зарубіжних науковців, проте необхідно звернути увагу на багатоваріантність використаних термінів: теорія бухгалтерського обліку, теорія обліку, основи бухгалтерського обліку, традиційний облік, традиційна облікова теорія, традиційний бухгалтерський облік, традиційна бухгалтерія, загальна теорія, базова теорія. Водночас, розкриття контенту використаного в роботах терміну, як правило, авторами не наводиться.

2. Контент-аналіз терміну «традиційна» стосовно бухгалтерського обліку та його теоріі. Еволюційний розвиток бухгалтерського обліку відбувається під впливом культурних, політичних, соціальних, історичних і природних особливостей траєкторії цивілізаційного розвитку певної країни і нації. Так, в Україні у свідомості науковців та бізнеспрактиків тривалий час панували усталені традиції обліку командно-адміністративної системи управління радянської епохи. Відкриття кордонів наприкінці XX століття надихнуло академічну спільноту до вивчення та активного пропагування теорій ринкової моделі економічної системи, тому традиційними вважають теорії і методи, які використовувалися до 1991 року. До критики, що лунає з боку вітчизняних науковців, відноситься і теорія бухгалтерського обліку, наприклад, Палій В. (2005) зазначає, що «... теорія бухгалтерського обліку відстає від сучасних потреб управління, оскільки вона сформувалася в тридцяті роки минулого століття в умовах централізованої планової економіки» [27, с. 46]. Водночас, пропонується два протилежно направлені вектори майбутнього розвитку: радикальний (революційний) - відмовитися від існуючої теорії і розробити нову; за іншим еволюційним, удосконалити існуючу.

Огляд публікацій зарубіжних вчених показує критику існуючого бухгалтерського обліку, яку більшість авторів із Свропи і США називають традиційним бухгалтерським обліком (traditional accounting) або загальним-загальноприйнятим (conventional accounting), при цьому слово «accounting» може перекладатися українською як «облік» без використання прийменника «бухгалтерський». Термінологічний аналіз сутності використаних термінів дозволяє стверджувати, що мова йде про облік за загальноприйнятими стандартами (financial accounting), у вітчизняному Законі про бухгалтерський облік і фінансову звітність» [28] - «бухгалтерський».

Необхідно звернути увагу, що вихід із ситуації, що склалася, а саме невідповідність традиційної (traditional, conventional) системи обліку новим умо- вам функціонування підприємств і компаній, а саме скорочення масового виробництва в середині 90-х років XX сторіччя, збільшення частки трудомісткого виробництва, превалювання цінності інтелектуальних ресурсів у складі активів, глобальної інформатизації, зарубіжні автори бачили у використанні інноваційних методик і технік управлінського обліку (management accounting), таких як Just-in-Time («Якраз вчасно»), Target costing (цільова собівартість), Kaizen (можливо mут мається на увазі Gemba Kaizen?) (постійне зниження витрат), Cost-killing: (максимальне зниження витрат), АВС (калькулювання за видами діяльності), Direct Costs (облік змінних і постійних витрат), LCC (розрахунок витрат за етапами життєвого циклу) та інших. «Нововведення неодмінно призвели до переформовування виробничої діяльності, моделі поведінки витрат виробництва, отже й методів обліку витрат» [29, с. 111].

Тим не менш, Johnson Т. (2006) підкреслював важливе значення саме даних фінансового обліку, які формується за допомогою точних правил. Законодавчі вимоги вимагають обов'язкового дотримання цих правил і унеможливлюють їх спрощення [30]. Іншими словами, фінансовий облік має повністю відповідати загальноприйнятим принципам бухгалтерського обліку (IFRS, GAAP, національним П(С)БО), нормам зовнішньої фінансової звітності та внутрішньофірмовим вимогам до звітності. Останнім часом спостерігаємо розширення інформації, що наводиться у звітах фінансової звітності i, яка розкриває аспекти соціальної відповідальності бізнесу і заходів щодо збереження довкілля.

Дослідженню теорії бухгалтерського обліку, як теоретичної основи обліку присвячено небагато публікацій. У своїй роботі Gaffikin M. (2016) піднімає питання втрати уваги науковців за останні сорок п'ять років до теорії бухгалтерського обліку (accounting theory), хоча раніше було багато спроб розробити теоретичну основу для обліку (theoretical base for accounting). Спочатку вони були в основному описами практики, але незабаром вони пішли по модерністському шляху [31, с. 109-142].

Незважаючи на суттєвий вплив факторів і тенденцій зовнішнього середовища, який детально досліджено у попередній роботі автора статті [32], та виникнення нових економічних теорій, як-то інституціональна, еволюційна, інтелектуальна тощо, в сфері бухгалтерського обліку досить скептично відносяться до зміни теорії бухгалтерського обліку, однак розглядають можливість адаптації системи бухгалтерського обліку до нових реалій в рамках усталеної теорії. 
Висновки та перспективи подальших досліджень. В результаті проведеного дослідження відповідно до поставлені мети отримані наступні висновки:

(1) Аналізування академічних текстів зарубіжних авторів демонструє аналогічну критику бухгалтерського обліку щодо невідповідності реальним змінам, що відбуваються на певному етапі розвитку економічної системи постіндустріального (інформаційного, інтелектуального, електронного, цифрового) суспільства під впливом культурних, політичних, соціальних, історичних і природних особливостей траєкторії цивілізаційного розвитку певної країни i нації. Проте зарубіжні колеги розділяють теорії бухгалтерського обліку, які вважають теоретичною основою або базою, до яких відносять, наприклад, теорію подвійного запису, та теорію фінансового обліку, яка лежить в основі стандартів, регламентуючих ведення обліку для складання фінансової звітності.

(2) Контент-аналіз дозволив виокремити об'єкти критики сучасними науковцями в сфері бухгалтерського обліку. Вітчизняні вчені критикують бухгалтерський облік та його теорію як теоретичну основу. В полі критики представників зарубіжної на- укової спільноти знаходяться облік, який включає фінансовий і управлінський, а також теорія фінансового обліку, яка лежить в основі введення обліку для складання фінансової звітності за загальноприйнятими стандартами, та, у найменшому ступені за останні два десятиліття, теорія бухгалтерського обліку, яка грунтується на визначенні методу та його елементів. Водночас, фіксуємо значний вплив західних тенденцій на розвиток поглядів вітчизняних вчених на теорію бухгалтерського обліку. Часовий розрив між напрямами наукових досліджень вітчизняних вчених та їхніх зарубіжних колег скорочується швидкими темпами.

Таким чином, вектор майбутнього розвитку обліку спрямований на адаптацію облікової системи української компанії до сучасних вимог щодо інформаційного забезпечення управління компанією: (1) дотримання положень законодавства країни і директив $\mathrm{CC}$, стандартів бухгалтерського обліку на національному і міжнародному рівнях; (2) забезпечення різноспрямованою та детальною інформацією для прийняття нестандартних рішень в умовах жорсткої конкуренції і складно прогнозованого стану зовнішнього середовища.

\section{Література}

1. Пушкар М.С. Тенденції та закономірності розвитку бухгалтерського обліку в Україні (теоретикометодологічні аспекти): моногр. Тернопіль: Економічна думка, 1999. 421 с. 2007. 359 c.

2. Пушкар М.С. Метатеорія обліку, або якою повинна стати теорія: монографія. Тернопіль: Картбланш,

3. Пушкар М.С. Створення інтелектуальної системи обліку. Тернопіль : Карт бланш, 2007. 152 с.

4. Соколов Я.В. Национальные школы бухгалтерского учета / Интернетресурс для бухгалтеров URL: https://buh.ru/articles/documents/13360/ (дата звернення: 27.03.2020)

5. Кіндрацька Л. Теорія бухгалтерського обліку: сучасні реалії оновлення //Бухгалтерський облік і аудит. 2008. №12. С. 30-33.

6. Варичева Р.В. Поняття власного капіталу// існик Житомирського державного технологічного університету. Серія: економіка, управління та адміністрування. 2010. №2 (52) С. 81-85.

7. Яремко І.Й. Концепції і парадигми бухгалтерського обліку як система наукових основ теорії // Bicник Національного університету «Львівська політехніка». Менеджмент та підприємництво в Україні: етапи становлення і проблеми розвитку. 2010. № 691. С. 246-252.

8. Бутинець Ф.Ф., Бутинець Т.А. Теорія обліку чи його основи. Що вивчають майбутні фахівці з обліку? // Проблеми теорії та методології бухгалтерського обліку, контролю і аналізу. 2012 №1 (22). С. 19-37.

9. Жук В.М. Наукова гіпотеза трактування бухгалтерського обліку як соціально-економічного інституту // Облік і фінанси. 2012. №. 2. С. 14-22.

10. Рета М. В. Становлення і розвиток парадигми бухгалтерського обліку // Бізнес Інформ. 2014. № 10. C. 287-293. URL: http://nbuv.gov.ua/UJRN/binf_2014_10_48. (дата звернення: 27.03.2020)

11. Редченко К. І. До питання розвитку сучасних інформаційних систем обліку і контролю // Проблеми теорії та методології бухгалтерського обліку, контролю і аналізу. Сер.: Бухгалтерський облік, контроль і аналіз. 2014. №. 3. C.339-349.

12. Пушкар М.С., Семанюк В.3. Нове розуміння обліку в економіці знань // Вінниця: ВНHІЕ ТНЕУ. 2018. C. 95-97.

13. Семанюк В. Особенности и противоречия развития теории учета // Бухгалтерский учет и анализ, № 4. 2018. C. 44-48.

14. Хендриксен Е.С., Ван Бреда М. Ф. Теория бухгалтерского учета / Е.С. Хендриксен, М. Ф. Ван Бреда; пер. с англ. под ред. проф. Я. В. Соколова. М. : Финансы, 2000. 576 с.

43.

15. Maskell B.H., Baggaley B.L. Lean accounting: What's it all about? // Target Magazine. 2006. Vol. 1, P. 35-

16. Kennedy F.A., Brewer P.C. The lean enterprise and traditional accounting - Is the honeymoon over? // Journal of Corporate Accounting \& Finance. 2006. Vol. 6, P. 63-74. doi: 10.1002/jcaf.20234 
17. Cooper Robin ve Maskell, Brian. How to Manage Through Worse Before Better // MIT Sloan Management Review. 2008. Vol. 49(4), P. 58-65.

18. Bullen M.L., Eyler K. Human resource accounting and international development; implication for measurement of human capital // Journal of Internal business and Cultural Studies. 2010. Vol. 3, P. 1-16.

19. Maskell B., Baggaley B., Grasso L. Practical Lean Accounting. Second Edition, CRC Press, New York. 2012.

20. Rosa A.C, Machado M.J. Lean accounting: Accounting contribution for lean management philosophy // Tourism \& Management Studies. 2013. Vol. 12, P. 886-895.

21. McVay G., Kennedy F., Fullerton R. Accounting in the Lean Entreprise. CRC Press. New York. 2013.

22. Ofileanu D., Topor D.I. Lean AccountingAn Ingenious Solution for Cost Optimization // International Journal of Academic Research in Business and Social Sciences. 2014. Vol. 4, P. 3-42. doi: 10.6007/IJARBSS/v4-i4/793

23. Burritt R., Christ K. Industry 4.0 and environmental accounting: A new revolution? // Asian J. Sustain. Soc. Responsib. 2016. Vol. 1, P. 23-38. doi: 10.1186/s41180-016-0007-y

24. Schaltegger S., Etxeberria I.Á., Ortas E. «Innovating corporate accounting and reporting for sustainabilityattributes and challenges», Sustainable Development. 2017. Vol. 2, P. 113-122. doi: 10.1002/sd.1666

25.Chabrak N., Haslam J. and Oakes H. What is accounting? The "being" and "beings" of the accounting phenomenon and its critical appreciation // Accounting, Auditing \& Accountability Journal. 2019. Vol. 32. № 5, P. 1414-1436.

26. Myrelid A., Olhager J. Hybrid manufacturing accounting in mixed process environments: A methodology and a case study // International Journal of Production Economics. 2019. Vol. 210, P.137-144. doi: 10.1016/j.ijpe.2019.01.024

27. Палий В.Ф. Актуальные вопросы теории бухгалтерского учета // Бухгалтерский учет. 2005. № 3. C. $45-48$.

28. Про бухгалтерський облік і фінансову звітність в Україні: Закон України від 16.07.1999 р. № 996XIV за станом на 16.01.2020. URL: https://zakon.rada.gov.ua/laws/show/996-14\#Tехt (дата звернення: 23.03.2020)

29. Яценко В. Ф. Облік витрат виробництва: вплив тенденцій постіндустріального етапу розвитку суспільства // Науковий вісник Херсонського державного університету. Сер. Економічні науки. 2018. Т. 4. №. 30. C. $109-113$.

30. Johnson T. Lean accounting: to become lean, shed accounting // Cost Management. 2006. Vol. 20 (1). P. 6 17.

31. Gaffikin M.J.R. A Brief Historical Appreciation of Accounting Theory? But Who Cares? // Pioneers of Critical Accounting. Palgrave Macmillan, London, Springer, 2016. P. 109-142.doi: https://doi.org/10.1057/978-1-13754212-0_7

32. Яценко В.Ф. Вплив еволюційної трансформації соціально-економічної системи на теорію бухгалтерського обліку // Економіка харчової промисловості. 2019. Т.11, вип. 4. С. 71-79. doi: 10.15673/fie.v11i4.1549

Стаття надійшла 18.03.2020

Стаття прийнята до друку 1.04.2020

Доступно в мережі Internet 11.07.2020

\author{
Яценко В.Ф. \\ кандидат экономических наук, доцент \\ кафедра учета и налогообложения \\ Херсонский государственный аграрный университет \\ ул. Стритенская, 23, г. Херсон, Украина, 73006 \\ E-mail viktorijajacenko@gmail.com \\ ORCID ID: 0000-0001-7127-1885
}

\title{
ЧТО ТАКОЕ «ТРАДИЦИОННАЯ» ТЕОРИЯ БУХГАЛТЕРСКОГО УЧЕТА И ПОЧЕМУ ЕЕ КРИТИКУЮТ?
}

В представленной статье анализируются критические замечания, высказанные отечественными учеными, о существующей теории бухгалтерского учета. Их позиция сравнивается с позицией зарубежных авторов, а также обобщаются подходы к использованию термина «традиционная» применительно к учету и его теории, а также раскрывается его содержание и роль критики в определении вектора эволюционного развития учета. 
Критика современного состояния бухгалтерского учета и его теории объединила большинство отечественных и зарубежных ученых.Анализ академических текстов зарубежных авторов демонстрирует критику бухгалтерского учета в направлении несоответствия реальным изменениям, происходящим на определенном этапе развития экономической системы постиндустриального общества под влиянием культурных, политических, социальных, исторических и природных особенностей траектории цивилизационного развития определенной страны и нации. В то же время, фиксируем значительное влияние западных тенденций на развитие взглядов отечественных ученных на теорию бухгалтерского учета. Временной разрыв между направлениями научных изысканий отечественных ученых и их зарубежных коллег сокращается быстрыми темпами. Несоответствие традиционной системы учета новым условиям функционирования предприятий и компаний, зарубежные авторы видели в использовании инновационных методик и техник управленческого учета,

В сфрере бухгалтерского учета довольно скептически относятся к изменению теории бухгалтерского учета, однако рассматривают возможность адаптации системы бухгалтерского учета к новым реалиям в рамках устоявшейся теорий.

В единой учетной системе очерчивается четкое разграничение двух взаимосвязанных подсистем: стандартизированного финансового учета для отражения фрактического состояния компании и управленческого учета как учетно-аналитического обеспечения в соответствии с теориями и концепциями управления.

Ключевые слова: теория бухгалтерского учета, финансовый учет, управленческий учет, традиционная теория бухгалтерского учета, традиционный учет.

\author{
Yatsenko V. \\ Ph.D, Associate Professor \\ Department of Accounting and Taxation \\ Kherson State Agrarian University \\ str. Stritenskaya, 23, Kherson, Ukraine, 73006 \\ E-mail viktorijajacenko@gmail.com \\ ORCID ID: 0000-0001-7127-1885
}

\title{
WHAT "TRADITIONAL" THEORY OF ACCOUNTING MEANS AND WHY IS IT CRITICIZED?
}

The paper analyzes the critical comments of domestic scientists about the current accounting theory. There is a comparative analysis of opinions of domestic and foreign authors and summary of the approaches to using term "traditional" in respect to accounting and its theory. Content of accounting and role of criticism in the direction of evolutionary development of accounting are described. Criticism of the current state of accounting and its theory has united the majority of domestic and foreign scientists.

The analysis of foreign authors' papers reveals the criticism of accounting in the line of nonconformances with real changes that occur at the certain stage of the economic system development within post-industrial society under the influence of cultural, political, social, historical and natural specifics of the civilizational development direction of a particular country and nation. At the same time, we determine a significant influence of Western trends on the development of domestic scientists' opinions on accounting theory. Moreover, the time gap between the directions of scientific research of domestic and foreign scientists is shortening rapidly. Foreign authors presume the non-conformance between traditional (conventional) accounting system with the new operating conditions of enterprises and companies in the terms of the use of innovative methods and techniques of management accounting.

Within accounting, there is a sceptical view of accounting theory changes. However, the possibility of adapting the accounting system to new realities within the framework of established theories is being considered.

In a consistent accounting system, a clear line between two interconnected subsystems is coming up: standardized financial accounting to reflect the actual state of the company and management accounting as accounting and analytical support in a line with management theories and concepts.

Key words: accounting theory, financial accounting, management accounting, traditional accounting theory, traditional accounting, conventional accounting. 


\section{References}

1. Pushkar, M. S. (1999). Tendentsii ta zakonomirnosti rozvytku bukhhalterskoho obliku v Ukraini (teoretykometodolohichni aspekty).Ternopil: Ekonomichna dumka.

2. Pushkar, M. S. (2007). Metateoriia obliku, abo yakoiu povynna staty teoriia. Ternopil: Kartblansh.

3. Pushkar, M. S. (2007). Stvorennia intelektualnoi systemy obliku. Ternopil: Kart blansh.

4. Sokolov, Ya.V. Natsionalnyie shkolyi buhgalterskogo ucheta. Internetresurs dlya buhgalterov. Retrieved March 27, 2020, from https://buh.ru/articles/documents/13360/

5. Kindratska, L. (2008). Teoriia bukhhalterskoho obliku: suchasni realii onovlennia. Bukhhalterskyi oblik $i$ audyt, (12), 30-33.

6. Varycheva, R. V. (2010). Poniattia vlasnoho kapitalu. Visnyk Zhytomyrskoho derzhavnoho tekhnolohichnoho universytetu, (2 (52)), 81-85.

7. Yaremko, I. Y. (2010). Kontseptsii i paradyhmy bukhhalterskoho obliku yak systema naukovykh osnov teorii. Visnyk Natsionalnoho universytetu «Lvivska politekhnika». Menedzhment ta pidpryiemnytstvo v Ukraini: etapy stanovlennia i problemy rozvytku, (691), 246-252.

8. Butynets, F. F., Butynets, T. A. (2012). Teoriia obliku chy yoho osnovy. Shcho vyvchaiut maibutni fakhivtsi z obliku? Problemy teorii ta metodolohii bukhhalterskoho obliku, kontroliu i analizu. (1 (22)), 19-37.

9. Zhuk, V. M. (2012). Naukova hipoteza traktuvannia bukhhalterskoho obliku yak sotsialno-ekonomichnoho instytutu. Oblik i finansy, (2), 14-22.

10. Reta, M. V. (2014). Stanovlennia i rozvytok paradyhmy bukhhalterskoho obliku. Biznes Inform, (10), 287293. Retrieved March 27, 2020, from http://nbuv.gov.ua/UJRN/binf_2014_10_48.

11. Redchenko, K. I. (2014). Do pytannia rozvytku suchasnykh informatsiinykh system obliku i kontroliu. Problemy teorii ta metodolohii bukhhalterskoho obliku, kontroliu i analizu, (3), 339-349.

12. Pushkar, M. S., \& Semaniuk, V. Z. (2018). Nove rozuminnia obliku v ekonomitsi znan. Vinnytsia: VNNIE TNEU, 95-97.

13. Semanyuk, V. (2018). Osobennosti i protivorechiya razvitiya teorii ucheta. Buhgalterskiy uchet $i$ analiz, (4), 44-48.

14. Hendriksen, E.S., \& Van Breda, M. F. (2000). Teoriya buhgalterskogo ucheta (Ya. V. Sokolova, Trans.). Moscow: Finansyi.

15. Maskell, B.H., \& Baggaley, B.L. (2006). Lean accounting: What's it all about? Target Magazine, (1), 3543.

16. Kennedy, F. A., \& Brewer, P. C. (2006). The lean enterprise and traditional accounting - Is the honeymoon over? Journal of Corporate Accounting \& Finance, (6), 63-74. doi: 10.1002/jcaf.20234

17. Cooper Robin ve Maskell, Brian. (2008). How to Manage Through Worse Before Better. MIT Sloan Management Review, (49 (4)), 58-65.

18. Bullen, M. L., \& Eyler, K. (2010). Human resource accounting and international development; implication for measurement of human capital. Journal of Internal business and Cultural Studies. (3), 1-16.

19. Maskell, B., Baggaley, B., \& Grasso, L. (2012). Practical Lean Accounting (2nd ed.). CRC Press, New York.

20. Rosa, A. C, \& Machado, M. J. (2013). Lean accounting: Accounting contribution for lean management philosophy. Tourism \& Management Studies. (12), 886-895.

21. McVay, G., Kennedy, F., \& Fullerton, R. (2013). Accounting in the Lean Entreprise. New York: CRC Press.

22. Ofileanu, D., \& Topor, D. I. (2014). Lean AccountingAn Ingenious Solution for Cost Optimization. International Journal of Academic Research in Business and Social Sciences. (4), 3-42. doi: 10.6007/IJARBSS/v4-i4/793

23. Burritt, R., \& Christ, K. (2016). Industry 4.0 and environmental accounting: A new revolution? Asian J. Sustain. Soc. Responsib, (1), 23-38. doi: 10.1186/s41180-016-0007-y

24. Schaltegger, S., Etxeberria, I. Á., \& Ortas, E. (2017). Innovating corporate accounting and reporting for sustainability-attributes and challenges. Sustainable Development, (2), 113-122. doi: 10.1002/sd.1666

25. Chabrak, N., Haslam, J. \& Oakes, H. (2019). What is accounting? The "being" and "beings" of the accounting phenomenon and its critical appreciation. Accounting, Auditing \& Accountability Journal, 32 (5), $1414-1436$. doi: 10.1108/AAAJ-08-2017-3097

26. Myrelid, A., \& Olhager J. (2019). Hybrid manufacturing accounting in mixed process environments: A methodology and a case study. International Journal of Production Economics. 210, 137-144. doi: 10.1016/j.ijpe.2019.01.024

27. Paliy, V. F. (2005). Aktualnyie voprosyi teorii buhgalterskogo ucheta. Buhgalterskiy uchet, (3), 45-48.

28. Pro bukhhalterskyi oblik i finansovu zvitnist v Ukraini (2020). Zakon Ukrainy vid 16.07.1999 r. № 996XIV za stanom na 16.01.2020. Retrieved March 23, 2020, from https://zakon.rada.gov.ua/laws/show/996-14\#Text 
29. Yatsenko, V. F. (2018). Oblik vytrat vyrobnytstva: vplyv tendentsii postindustrialnoho etapu rozvytku suspilstva. Naukovyi visnyk Khersonskoho derzhavnoho universytetu, 4 (30), 109-113.

30. Johnson, T. (2006). Lean accounting: to become lean, shed accounting. Cost Management, 20 (1), 6-17.

31. Gaffikin, M.J.R. (2016). A Brief Historical Appreciation of Accounting Theory? But Who Cares?. In: J. Haslam, P. Sikka P. (eds), Pioneers of Critical Accounting. Palgrave Macmillan, London, Springer. doi: 10.1057/978-1-137-54212-0_7

32. Yatsenko, V. F. (2019). Vplyv evoliutsiinoi transformatsii sotsialno-ekonomichnoi systemy na teoriiu bukhhalterskoho obliku. Food Industry Economics, 11 (4), 71-79. doi: 10.15673/fie.v11i4.1549

Received 18 March 2020

Approved 1 April 2020

Available in Internet 11.07.2020

Цитування згідно ДСТУ 8302:2015

Яценко В.Ф. Що таке «традиційна» теорія бухгалтерського обліку та чому ії критикують? 2020. Т.12, вип. 2. С. 82-90. doi: 10.15673/fie.v12i2.1744

Cite as APA style citation

Yatsenko, V. (2020). What "traditional" theory of accounting means and why is it criticized? Food Industry Economics, 12(2), 82-90. doi: 10.15673/fie.v12i2.1744 